\title{
Miten voimme ottaa huomioon ikääntyvien terveystietokäyttäytymisen digitaalisten terveyspalveluiden kehittämisessä
}

\author{
Isto Huvila \\ Institutionen för ABM, Uppsala universitet ja Informationsvetenskap, Åbo Akademi \\ isto.huvila@abo.fi \\ https://orcid.org/0000-0001-9196-2106
}

Heidi Enwald

Informaatiotutkimus, Oulun yliopisto ja Informationsvetenskap, Åbo Akademi

heidi.enwald@oulu.fi

https: //orcid.org/0000-0003-1953-2157

Kristina Eriksson-Backa

Informationsvetenskap, Åbo Akademi

kristina.eriksson-backa@abo.fi

https://orcid.org/0000-0001-9758-0467

Noora Hirvonen

Informaatiotutkimus, Oulun yliopisto

noora.hirvonen@oulu.fi

https://orcid.org/0000-0001-7577-3057

Asiasanat: terveyspalvelut, terveyskäyttäytyminen, informaatiokäyttäytyminen, sähköiset palvelut, ikääntyneet, aikuiset, käyttäjäkeskeinen suunnittelu

Artikkeli on lisensoitu Creative Commons Nimeä-EiKaupallinen-JaaSamoin 4.o Kansainvälinen -lisenssillä Pysyvä osoite: https://doi.org/10.23978/inf.98633 


\section{Johdanto}

Digitaalisia terveyspalveluita, mukaanlukien potilasfoorumeja, sähköisiä potilasarkistoja, mobiileja terveyspalveluita ja omaseurantajärjestelmiä, kehitetään ja otetaan käyttöön ympäri maailmaa koko ajan. Palveluille on usein asetettu monia tavoitteita ja niiltä odotetaan hyötyjä niin yksityisellä kuin yhteiskunnallisella tasolla. Suurista odotuksista huolimatta ei ole epätavallista, että palvelut eivät vastaa niille asetettuja tavoitteita. Yksi keskeisistä ongelmista on, että palveluita kehitetään usein yksittäin huomioimatta sitä, että palveluita käyttävien kansalaisten arkipäivässä sähköinen terveyspalvelu on osa laajempaa kokonaisuutta: terveystietoa haetaan samanaikaisesti monista lähteistä ja yksittäinen palvelu tai järjestelmä avautuu käyttäjille osana heidän laajempaa terveystietokäyttäytymistään.

Tämän tekstin tavoitteena on raportoida viisivuotisen Suomen Akatemian rahoittaman projektin Hälsoinformationsbeteende i e-hälsokontext: inverkan av ett negligerat element i framgångsrik implementering av konsumentinriktade hälsoteknologier för äldre vuxna (lyh. HIBA, suom. Terveystietokäyttäytyminen e-terveyskontekstissa: laiminlyödyn tekijän vaikutus kuluttajasuuntautuneiden terveysteknologioiden menestyksellisessä toteuttamisessa) keskeisiä tuloksia. Projektin tavoitteena on ollut selvittää lähtökohtia sellaisten sähköisten terveyspalveluiden kehittämiselle, jotka ovat ymmärrettäviä, merkityksellisiä ja käyttökelpoisia ikääntyville aikuisille siinä, miten he etsivät, käyttävät ja hallitsevat tietoa ja erityisesti terveystietoa arkipäiväisessä elämässään.

\section{Menetelmät}

HIBA-projektissa tutkittiin suomalaisten 50-70-vuotiaitten aikuisten terveystietokäyttäytymistä, terveystiedon lukutaitoa ja käsityksiä digitaalisista terveystietopalveluista sekä laadullisin että määrällisin menetelmin. Tutkimus keskittyi ikäryhmään, joka aiemman tutkimuksen mukaan käyttää verrattain vähän digitaalisia terveystietopalveluita, mutta jonka osuus väestöstä on kasvamassa nopeasti ja jossa terveyspalveluiden tarpeen voidaan olettaa kasvaa nopeasti ikääntymisen myötä.

Tutkimusta taustoitti systemaattinen kirjallisuuskatsaus, jonka avulla koottiin yhteen aikaisempaa tutkimusta ikääntyvien aikuisten käsityksistä digitaalisista terveyspalveluista. Projektin puitteissa toteutettiin fokusryhmähaastatteluita sekä kansallinen postikyselytutkimus edustavalle otokselle suomen- ja ruotsinkielisiä 50-70-vuotiaita aikuisia kesällä 2019. 
Esimerkkinä ja vertailukohtana digitaalisista terveyspalveluista projektissa käytettiin valtakunnallista Omakanta-palvelua, jonka - toisin kuin kunnallisten tai alueellisten digitaalisten terveyspalveluiden - voitiin olettaa olevan tuttu ympäri maan. Projektissa tehtiin lisäksi yhteistyötä ruotsalaisten tutkijoiden kanssa analysoiden sikäläisten ikääntyvien aikuisten näkemyksiä ja kokemuksia digitaalisten terveyspalveluiden käytöstä paikallisten kyselyaineistojen avulla.

\section{Tuloksia}

Systemaattisen kirjallisuuskatsauksen tulokset osoittavat, että aikaisemmassa tutkimuksessa on keskitytty järjestelmien tekniseen käytettävyyteen pikemminkin kuin siihen, miten käytännöllisiä ja hyödyllisiä e-terveyspalvelut ovat niiden käyttäjille ja miten hyvin ne vastaavat käyttäjien jokapäiväisiin tarpeisiin. Yleisesti ottaen aikaisempi tutkimus on lähestynyt e-terveyspalvelujen käyttöä monista eri kysymyksenasetteluista. Tavallisia teemoja ovat palveluiden käyttötavat, käyttöä helpottavat ja haittaavat tekijät, ja käytön seuraukset. Kirjallisuuskatsauksessa havaittiin myös, että käytetty tutkimusmenetelmä vaikuttaa siihen, millaisia tuloksia tutkimuksissa raportoidaan. Erityisesti määrälliset kyselytutkimukset ovat taipuvaisia raportoimaan positiivisia tuloksia (Hirvonen et al., 2020).

Tutkimus, jossa tarkasteltiin omia potilaskertomuksia kotiin tilanneiden ruotsalaisten ikääntyvien aikuisten toiveita ja tarpeita potilaskertomustiedon ja e-terveyspalveluiden suhteen osoitti, että eläkeiän kynnys on elämänvaihe, jossa terveystiedon tarpeet kasvavat ja suhde terveyteen, terveydenhoitoon ja terveystietoon muuttuvat (ks. esim. Huvila et al., 2018). Alustavat tulokset suomalaisten ikääntyvien aikuisten käsityksistä Omakanta palvelusta osoittavat, että vastaajien huolenaiheet ja järjestelmän käyttöä estävät syyt koostuvat sosiaalisten, teknisten ja informaatioon liittyvien tekijöiden yhdistelmistä ja riippuvat järjestelmän tarjoamasta informaatiosisällöstä. Yleisesti ottaen vaikuttaa lisäksi siltä, että tarjolla olevan informaation ajantasaisuus ja koherenssi ovat tärkeitä käyttäjille.

Lukuisten määrällisten kyselytutkimusten tulokset ja informaatiolukutaidon ja teknologioiden käytön vertailut eri ikäryhmissä viittaavat siihen, että ikääntyvät aikuiset pitävät terveystietoa tärkeänä mutta tiedon löytäminen ja ymmärtäminen on vaikeaa (Hirvonen et al., 2020). Ikääntyvillä aikuisilla, joiden käsitykset omista informaatiolukutaidollisista kyvyistään ovat heikot, on usein vähemmän kokemusta mobiilien informaatioteknologioiden käytöstä ja suhtautuvat niihin kielteisesti (Enwald et al., 2017). Toisaalta, 
terveystiedon lukutaito ei vaikuta paranevan vaan ennemminkin muuttuvan iän myötä suhteessa eri ikävaiheisiin liittyviin haasteisiin (Huvila et al., 2019a).

Havaintoja ikääntyvien aikuisten terveystietokäyttäytymisestä on hedelmällistä verrata myös yleisiin toimintamalleihin. Aktiiviset, laaja-alaiset ja oma-aloitteiset tiedonhankkijat vaikuttavan olevan usein aktiivisia myös muussa toiminnassaan, mikä viittaa Matteus-vaikutukseen (ErikssonBacka \& Nguyen, 2020). Vaikka esimerkiksi krooninen sairaus on usein merkittävä tekijä, joka vaikuttaa terveytietokäyttäytymiseen, ei se välttämättä aina muuta käyttäytymistä. Joissakin tapauksissa terveeksi itsensä kokevat yksilöt saattavat olla halukkaampia muuttamaan toimintaansa (Nguyen et al., 2018; Eriksson-Backa \& Nguyen, 2020). Samantyyppiset kokemukset ja ongelmat eivät näin ollen aina johda samantyyppisiin johtopäätöksiin ja toimintamalleihin eri ikäryhmissä tai laajemmin (esim. Huvila et al., 2018 vs. Huvila et al., 2015).

Terveystietoon ja e-terveyspalveluihin liittyvien kysymyksenasettelujen kautta projektin puitteissa on lähestytty myös laajemmin tietokäyttäytymistutkimuksen ja järjestelmä- ja palvelusuunnittelun välistä kuilua, sen syitä ja mahdollisia tapoja lähentää tutkimusalueita keskenään (Huvila et al., 2019c). Laajempi vertailu eri tieteen- ja käytännön alojen välillä osoittaa, että kapeat ja teknologiaan keskittyvät tutkimus- ja toiminta-asetelmat eivät ole tavallisia vain terveystietoon liittyvissä kysymyksissä. Tästä syystä toisista yhteyksistä lainatut toimintatavat voivat olla käyttökelpoisia ja auttaa parempien järjestelmien ja palveluiden suunnittelemisessa eri konteksteissa.

\section{Loppupäätelmiä}

Projektin tulokset korostavat ihmisten tietokäyttäytymisen, sosio-taloudellisen elämänpiirin ja teknologioiden välisiä yhteyksiä ja tarvetta tarkastella niitä kokonaisuutena. Palveluiden käyttäjien käyttäytymisen ja käytänteiden ja palveluiden konkreettisen hyödyllisyyden ymmärtäminen on keskeistä olemassaolevien palveluiden kehittämisessä ja uusien suunnittelussa. Tutkimustulokset viittaavat siihen, että ikä on hyödyllinen indikaattori terveystietokäyttäytymisen ymmärtämisessä. Sitä ei kuitenkaan ole syytä käyttää niinkään osoituksena siitä, että tietyissä ikävaiheissa jokaisen yksilön toimintamallit muuttuvat samankaltaiseen suuntaan vaan pikemminkin siitä, että ihmisillä on tietyissä elämänvaiheissa samantapaisia ongelmia ja haasteita, joihin he reagoivat eri tavoilla. Projektin tulosten perusteella voidaan todeta, että vanhoja aikuisia voitaisiin aikaisempaa enempää ohjata ja auttaa ikääntyvinä ja terveydestään nuorempiaan hiljalleen eri tavalla kiinnostuneina yksilöinä 
kohti uusia heille käyttökelpoisempia palveluita sen sijaan, että heitä käsitellään joko kykenevinä ja osaavina tai vähemmän kykenevinä ja osaavina yksittäisten palveluiden käyttäjinä. Lisäksi vaikuttaa siltä, että laajempi kysymys tiedon ja informaatiosisällön, eri järjestelmien ja palveluiden, terveyden ja iän välisestä suhteesta kaipaa lisää selvittämistä.

\section{Lähteet}

Enwald, H., Hirvonen, N., Kangas, M., Keränen, N., Jämsä, T., Huvila, I., \& Korpelainen, R. (2017). Relationship between everyday health information literacy and attitudes towards mobile technology among older people. In: Kurbanoğlu, S., et al. (Eds) Information Literacy in the Workplace: 5th European Conference, ECIL 2017. Saint-Malo, France. Berlin: Springer, pp. 450-459. https://doi.org/10.1007/978-3-319-74334-9_47

Eriksson-Backa, K., \& Nguyen, H. (2020). Health information-seeking styles and health information literacy in relation to anticipated health-promoting behaviour-results from an online diabetes risk test survey. International Journal of Telemedicine and Clinical Practices 3(3), 192-208. https://doi.org/10.1504/ijtmcp.2020.10026525

Hirvonen, N., Enwald, H., Känsäkoski, H., Eriksson-Backa, K., Nguyen, H., Huhta, A.-M., \& Huvila, I. (2020). Older adults' views on eHealth services: a systematic review on scientific journal articles. International Journal of Medical Informatics, 135, 235-248. https://doi. org/10.1016/j.ijmedinf.2019.104031

Huvila, I., Enwald, H., Eriksson-Backa, K., Hirvonen, N., Nguyen, H., \& Scandurra, I. (2018). Anticipating aging: Older adults reading their medical records. Information Processing \& Management, 54(3), 394-407. https://doi.org/10.1016/j.ipm.2018.01.007

Huvila, I., Hirvonen, N., Enwald, H., \& Åhlfeldt, R.-M. (2019). Differences in health information literacy competencies among older adults, elderly and younger citizens. In: Kurbanoğlu, S., Špiranec, S., Ünal, Y., Boustany, J., Huotari, M. L., Grassian, E., Mizrachi, D., \& Roy, L. (Eds.) Information Literacy in Everyday Life. ECIL 2018, pp. 136-143. Springer. https://doi. org/10.1007/978-3-030-13472-3_13 (Huvila et al. 2019a)

Huvila, I., Moll, J., Enwald, H., Hirvonen, N., Åhlfeldt, R., \& Cajander, Å. (2019). Age-related differences in seeking clarification to understand medical record information. In: Proceedings of ISIC, The Information Behaviour Conference. 2018 Oct 9-11; Krakow, Poland. Information Research 2019, 24(1), isic1834. (Huvila et al. 2019b)

Huvila, I., Enwald, H., Eriksson-Backa, K., Liu, Y.-H., \& Hirvonen, N. (2019). Information behaviour and practices research informing technology and service design. Proceedings of the Association for Information Science and Technology 56(1), 541-545. ASIS\&T 2019, Melbourne, Australia. https://doi.org/10.1002/pra2.86 (Huvila et al. 2019c)

Nguyen, H., Eriksson-Backa, K., \& Enwald, H. (2018). Preliminary Results of a Survey on User Opinions and Experiences on an Online Diabetes Risk Test. PACIS 2018 Proceedings. 114. Retrieved from https://aisel.aisnet.org/pacis2018/114 